\title{
LAMPRÓFIROS ALCALINOS DO ARQUIPÉLAGO DE FERNANDO DE NORONHA
}

\author{
V.Maríngolo ${ }^{1}$ \\ M.N.C.Ulbrich ${ }^{2}$
}

$\mathrm{Na}$ ilha principal do Arquipélago de Fernando de Noronha ocorrem numerosos diques de rochas ultrabásicas integrando a grande variedade de rochas vulcânicas-subvulcânicas que compõem a Formação Remédios, o mais antigo evento magmático exposto (ALMEIDA, 1955; DNPM, Monografia XIII).

O estudo petrográfico de 38 lâminas dessas rochas mostrou que várias delas são típicos lamprófiros, constantes das descrições de ALMEIDA (1955), representando todas as variedades de lamprófiros alcalinos conhecidas.

As rochas possuem texturas porfirfticas-glomeroporfiriticas com teores variáveis de olvina parcial ou totalmente alterada, titanoaugita - com núcleos ou zonas de soda augita-egirina augita de cor verde e pleocroísmo fraco - e anfibólio kersutítico. Na matriz ocorrem os mesmos minerais, exceto olivina, junto com grãos opacos, apatita em quantidades acessórias, rara biotita, vidro intersticial e/ou minerais félsicos; os últimos, em rochas com vidro, podem faltar ou ser muito escassos, Os minerais félsicos estão confinados à matriz das rochas, exceto os feldspatóides do grupo da sodalita (haüyna, noseana) que, quando presentes, podem ocorrer ora como fenocristais, ora unicamente na matriz. Os minerais máficos da matriz são idiomórficos, mas os fenocristais podem aparecer reabsorvidos, principalmente a olivina. São comuns as estruturas globulares contendo carbonatos e/ou zeólitas, às vezes clorita e até snica micro/criptocristalina.

A classificação recente da IUGS identifica os lamprófiros alcalinos utilizando o tipo e as proporções relativas dos minerais félsicos e/ou do vidro presentes na matriz. Estes critérios

\footnotetext{
${ }^{1}$ Pós-graduação, Departamento de Mineralogia e Petrologia, Instituto de Geociências, USP.

${ }^{2}$ Departamento de Mineralogia e Petrologia, Instituto de Geociências, USP.
} 
permitem reconhecer no arquipélago: a) monchiquitos, com vidro (em parte, com início de devitrificação) incluíndo aí os tipos sem olivina, antigamente denominados de furchitos (ALMEIDA, 1955) rochas estas, com fenocristais de titanoaugita e abundante anfibólio, que estão entre os lamprófiros mais caracterizados da região; b) sannaftos, com feldspato potássico e mineral do grupo da sodalita, subordinado; e c) camptonitos, com ripas de plagioclásio em matriz zeolitica com analcima (?).

Existem outros diques mostrando rochas semelhantes aos lamprófiros típicos, mas nas quais o anfibólio e a biotita aparecem apenas na matriz, em quantidades subordinadas ou até acessórias (<5\%). Nessas rochas, mais ricas em olivina, são mais escassos os piroxênios sódicos como zonas em titanoaugitas - e faltam quase por completo as estruturas globulares. $O$ material estudado parece indicar que existe uma variação grande no teor de minerais hidratados nessas rochas de dique. Um exemplo da ausência de minerais máficos hidratados é o dos limburgitos, formando vários diques na região, que apresentam fenocristais idiomórficos de titanoaugita (às vezes com núcleos verdes), e olivina, em matriz vítrea com micrólitos de clinopiroxênio e grãos opacos.

Estudos de química mineral, em andamento, certamente fornecerão elementos para a melhor caracterização dos diques ultrabásicos. Alguns dados químicos e a mineralogia indicam que essas rochas tem afinidade basanítica-tefrítica, com os típicos lamprófiros sendo mais ricos em voláteis. 